\title{
PENGARUH BAURAN PEMASARAN TERHADAP KEPUTUSAN PEMBELIAN ES KRIM SAYUR BROCO ES KRIM DI PEKANBARU
}

\author{
Oleh \\ ${ }^{1)}$ Sudarmin Manik ${ }^{2)}$ Bunga Rianti \\ ${ }^{1)}$ S) Sekolah Tinggi Ilmu Ekonomi Riau \\ Jalan HR. Subrantas No. 57 Panam-Pekanbaru \\ ${ }^{1)}$ Email: aminmanik82@gmail.com \\ ${ }^{2)}$ Email: bungarianyi@gmail.com
}

\begin{abstract}
Abstrak
Penelitian ini dilakukan di Broco Es Krim Pekanbaru. Tujuan penelitian ini adalah untuk mengetahui pengaruh bauran pemasaran terhadap keputusan pembelian. Populasi yang ada dalam penelitian ini sebanyak 806 orang. Dalam penelitian ini pengambilan sampel menggunakan asidental sampling, yaitu sebesar 89 orang. Data yang digunakan adalah data primer dan sekunder dengan analisis menggunakan regresi linier berganda. Hasil penelitian menunjukkan hasil regresi linier $Y=2,847+0,464 X 1-0,127 X 2+$ $0,413 X 3+0,5936 X 4+e$. Berdasarkan perhitungan nilai $R=0,881$, Hal ini berarti product, price, place dan promotion memiliki hubungan yang sangat erat terhadap keputusan pembelian. Sedangkan nilai adjusted $R$ square sebesar 0,767, hal ini menunjukkan bahwa variabel product, price, place dan promotion berpengaruh sebesar 77,6\% pada keputusan pembelian Brocco es krim. Sisanya 22,4\% dipengaruhi oleh faktor lain yang tidak dibahas dalam penelitian ini seperti merek produk dan tingkat pendapatan.
\end{abstract}

Kata Kunci Product, Price, Place dan Promotion, Keputusan Pembelian

\begin{abstract}
This research was conducted at Broco Ice Cream, Pekanbaru. The purpose of this study was to determine the effect of the marketing mix on the purchasing decision of Brocco ice cream. The population in this study was 806 people. In this study the sampling uses incidental sampling, which is equal to 89 people. The data used are primary and secondary data with analysis using multiple linear regression. The results showed that the results of linear regression were $Y=2,847+0,464 X 1-0,127 X 2+0,413 X 3+0,5936 X 4+e$, Based on the calculation of the value of $R=0.881$, this means that Product, Price, Place and Promotion have a very close relationship with the purchasing decision. While the adjusted $R$ square value is 0.767 . This shows that the Product, Price, Place and Promotion variables have an effect of $77.6 \%$ on the purchase decision of Brocco ice cream. . The remaining $22.4 \%$ is influenced by other factors not discussed in this study such as product brands and income levels.
\end{abstract}

Keywords: Product, Price, Place dan Promotion, Purchase Decision

\section{PENDAHULUAN}

Saat ini es krim sudah menjadi produk makanan yang mudah ditemui dan merupakan salah satu produk yang kaya akan inovasi. Banyaknya bentuk dan berbagai macam rasa es krim membuat konsumen dapat memiliki banyak pilihan. Persaingan dalam produk es krim pun juga semakin ketat, dengan bermunculan dari berbagai perusahaan es krim dengan skala UKM yang bersaing dalam penjualan es krim.

Untuk itu memungkinkan konsumen untuk lebih sering mengkonsumsi es krim, terlebih pada musim panas. Mengingat konsumen es krim terdiri dari berbagai kalangan usia dan sosial, terutama kalangan usia 5 sampai 20 tahun, berarti industri es krim memiliki peluang pasar yang luas sehingga banyak bermunculan produsen-produsen es krim lainnya di pasaran. 
Walaupun pada saat ini keadaan perekonomian Indonesia sedang tidak stabil, tetapi para produsen es krim tetap berusaha untuk dapat terus memenuhi kebutuhan dan keinginan konsumennya. Semakin meningkatnya persaingan diantara merek-merek es krim yang telah beroperasi di pasar, menyebabkan hanya merek es krim yang memiliki citra merek kuat saja yang akan tetap mampu bersaing, merebut dan menguasai pasar.

Menurut Tjiptono (2015), citra merek (Brand Image) yakni tentang asosiasi dan keyakinan konsumen terhadap merek tertentu. Hal tersebut dikarenakan citra merek dapat mempengaruhi rasa percaya diri konsumen dalam pengambilan keputusan pembelian, sehingga mempertinggi keberhasilan program perusahaan es krim dalam memikat konsumen baru atau merangkul kembali konsumen lama.

Salah satu produk eskrim yang sangat diminati oleh konsumen di Pekanbaru saat ini adalah Brocco es krim. Di Pekanbaru sendiri Brocco es krim tetap menjadi produk pada kategori es krim yang cukup diminati dibandingkan merek UKM lainnya. Harga dari Brocco es krim cukup mahal jika dibandingkan dengan Es krim lainnya. Produknya yang memiliki variasi produk cukup banyak dan hanya dijual di lokasi tertentu di kota Pekanbaru, dan adanya promosi yang kuat dari Broco Ice Cream pada sosial media membantu menumbuhkan minat beli dari konsumen, sehingga berdampak pada keputusan pembelian konsumen.

Brocco es krim dikenal sangat baik dibenak konsumen di Pekanbaru karena Brocco es krim merupakan es krim sayur yang baik untuk kesehatan. Selain itu citra merek dari Brocco es krim dimata konsumen juga cukup besar dibandingkan dengan UKM lainnya, namun hal ini tentu menjadi efek dari baiknya bauran pemasaran yang di lakukan oleh perusahaan Brocco es krim. Brocco es krim sendiri memiliki segmen yang berbeda dengan jenis yang lebih banyak disukai oleh anak-anak. Jumlah pelanggan Broco es krim setiap tahunnya selalu mengalami peningkatan seperti pada tabel berikut:

Tabel 1. Jumlah Pelanggan Brocco Es Krim dari tahun 2014 sampai tahun 2018 di Pekanbaru

\begin{tabular}{|c|c|c|}
\hline No. & Tahun & Jumlah \\
\hline 1 & 2014 & 490 \\
\hline 2 & 2015 & 523 \\
\hline 3 & 2016 & 678 \\
\hline 4 & 2017 & 770 \\
\hline 5 & 2018 & 806 \\
\hline
\end{tabular}

Sumber : Brocco Es Krim, 2019

Dari tahun 2014 jumlah pelanggan Broco es krim berjumlah 490 pelanggan dan meningkat menjadi 806 pelanggan pada tahun 2018. Brocco es krim membuat beragam dari macam rasa dan bentuk untuk merebut berbagai segmen yang berbeda di pasar es krim yang ada di Pekanbaru. Hal ini tentu dilakukan untuk menjaga agar para kompetitor memiliki peluang yang sedikit dalam melakukan penjualan es krim dan dengan nama Brocco es krim yang telah lama dikenal tentu memudahkan penjualan es krim di kota Pekanbaru. Selain itu Brocco es krim juga memiliki kualitas es krim yang telah teruji dengan sertifikasi halal dan terdaftar di BPOM.

Untuk harga Brocco es krim lebih mahal dari produsen es krim lainnya, bahkan dari es krim yang sudah terkenal secara nasional seperti es krim Wall's, Campina dan Diamond. Harga kemasan 100ml dibandrol dengan harga Rp8.000,- sedangkan untuk harga 200ml dibandrol dengan harga Rp12.000,-dengan varian Brokoli, buah Naga, buah Beet, Wortel, Jagung, Ubi Ungu, Green Tea, Kurma, Pisang dan Kacang Merah. Seperti pada tabel berikut: 
Tabel 2 Kemasan dan Harga Brocco Es Krim

\begin{tabular}{|c|c|c|}
\hline No. & Kemasan & Harga \\
\hline 1 & $\begin{array}{c}\text { Kemasan 100 ml (varian Brokoli, buah Naga, } \\
\text { buah Beet, Wortel, Jagung, Ubi Ungu, Green } \\
\text { Tea, Kurma, Pisang dan Kacang Merah }\end{array}$ & Rp. 8.000 \\
\hline 2 & $\begin{array}{c}\text { Kemasan 200 ml (varian Brokoli, buah Naga, } \\
\text { buah Beet, Wortel, Jagung, Ubi Ungu, Green } \\
\text { Tea, Kurma, Pisang dan Kacang Merah }\end{array}$ & Rp. 12.000 \\
\hline
\end{tabular}

Untuk penjualan es krim dari tahun 2014 hingga tahun 2018 selalu mengalami kenaikan setiap tahunnya dari Rp58.500.000 pada tahun 2014 menjadi 61.500 .000 pada tahun 2018, seperti pada tabel berikut:

Tabel 3. Penjualan Brocco Es Krim dari tahun 2014 sampai tahun 2018 di Pekanbaru

\begin{tabular}{|c|c|c|}
\hline No. & Tahun & Jumlah \\
\hline 1 & 2014 & 58.500 .000 \\
\hline 2 & 2015 & 56.200 .000 \\
\hline 3 & 2016 & 63.300 .000 \\
\hline 4 & 2017 & 59.600 .000 \\
\hline 5 & 2018 & 61.500 .000 \\
\hline
\end{tabular}

Sumber : Brocco Es Krim, 2019

Pada tabel diatas penjualan Brocco es krim bersifat fluktuatif dan tidak selalu mengalami peningkatan dalam penjualan. Pada tahun 2015 dan tahun 2017 mengalami penurunan pendapatan sebesar menjadi Rp56.200.000 pada tahun 2015 dan 59.600.000 pada tahun 2017 . Hal ini tentu ada yang menjadi penyebab dari turun dan naiknya penjualan dari es krim. Walaupun Brocco es krim mempunyai segmen tertentu, namun Brocco es krim belum mendapatkan peningkatan penjualan dalam tahap yang konstan. Hal ini tentu cukup menarik karena hal ini dapat dimanfaatkan oleh para pesaing untuk memperkuat strategi pemasaran mereka dan merebut pangsa pasar yang ada.

Dengan semakin banyaknya pesaing yang muncul dalam persaingan bisnis es krim di Kota Pekanbaru tentu akan membuat perusahaan untuk membuat strategi yang tepat dalam menghadapi para kompetitor. Untuk itu perlu diukur seberapa besar pengaruh bauran pemasaran dalam menimbulkan minat beli dan keputusan pembelian. Sehingga diperlukan penelitian yang berjudul PENGARUH BAURAN PEMASARAN TERHADAP KEPUTUSAN PEMBELIAN ES KRIM SAYUR BROCO ES KRIM DI PEKANBARU.

\section{RUMUSAN MASALAH}

Rumusan masalah dalam penelitian ini adalah "Apakah bauran pemasaran berpengaruh positif dan signifikan terhadap keputusan pembelian Brocco es krim".

\section{Tujuan Penelitian}

Tujuan dalam penelitian ini adalah untuk menganalisis pengaruh bauran pemasaran terhadap keputusan pembelian Brocco es krim.

\section{Penelitian Terdahulu}

Penelitian yang dilakukan oleh Gunawan Prasetyo dari Universitas Mercu Buana Jakarta Pada Tahun 2013 dengan judul Pengaruh Bauran Pemasaran Terhadap Keputusan Pembelian (studi kasus Baskin Robbins Ice Cream Puri Mall). Hasil penelitian ini menunjukkan secara 
bersama-sama semua variabel yaitu produk, harga, saluran distribusi dan promosi berpengaruh terhadap keputusan pembelian. Variabel Produk saja yang mempengaruhi kepuasan konsumen secara parsial, sedangkan faktor harga, saluran distribusi dan promosi berpengaruh tidak signifikan terhadap keputusan pembelian.

Penelitian yang dilakukan oleh Mellya Silviana di Universitas Negeri Padang pada tahun 2011 dengan judul pengaruh produk, harga, promosi dan saluran distribusi terhadap keputusan pembelian ulang ice cream Wall's pada siswa SMP dan SMA di Kota Padang. Hasil penelitian berdasarkan analisis jalur menunjukkan bahwa: (1) Variabel produk berpengaruh langsung sebesar 6,86\% dan berpengaruh tidak langsung sebesar 1,53\% terhadap keputusan pembelian ulang ice cream Wall's, (2) Variabel harga berpengaruh langsung sebesar 6,45\% dan berpengaruh tidak langsung sebesar $-12,41 \%$ terhadap keputusan pembelian ulang ice cream Wall's, (3) Variabel promosi berpengaruh langsung $14,82 \%$ dan pengaruh tidak langsung sebesar $4,11 \%$ terhadap keputusan pembelian ulang ice cream Wall's, (4) Variabel saluran distribusi berpengaruh langsung 6,95\% dan pengaruh tidak langsung sebesar $12,07 \%$ terhadap keputusan pembelian ulang ice cream Wall's, sedangkan 66,57\% dipengaruhi oleh faktor lain di luar penelitian ini.

Penelitian yang dilakukan oleh Ridha Agustina di Universitas Mahasaraswati pada tahun 2017 dengan judul pengaruh bauran pemasaran terhadap keputusan pembelian konsumen produk ice cream Walls pada arena hiburan Tiara Dewata Denpasar. Hasil penelitian mendapatkan bahwa persamaan regresi yang terbentuk adalah $\mathrm{Y}=0,575+0,484 \mathrm{X} 1+0,238$ $\mathrm{X} 2+0,355 \mathrm{X} 3+0,251 \mathrm{X} 4$, hasil penelitian menunjukkan bahwa produk (X1) mempunyai pengaruh yang paling besar dibandingkan dengan variabel bebas lainnya terhadap keputusan pembelian konsumen produk ice cream Wall's pada arena hiburan Tiara Dewata Denpasar, dengan nilai square sebesar $69,2 \%$ dan sisanya $41,8 \%$ diikuti oleh variabel lain yang tidak diteliti dalam penelitian ini, serta hasil nilai analisis korelasi sebesar 0,832 yang berarti memiliki korelasi yang tinggi. Dari uji diperoleh hasil secara parsial bauran pemasaran berpengaruh positif dan signifikan terhadap keputusan pembelian produk ice cream Wall's, sedangkan dari hasil uji $\mathrm{F}$ secara simultan bauran pemasaran berpengaruh positif dan signifikan terhadap keputusan produk ice cream wall's dimana nilai Fhitung $>$ Ftabel.

Penelitian yang dilakukan oleh Desi Andriani di STIE Riau pada tahun 2018 dengan judul pengaruh bauran pemasaran terhadap keputusan pembelian jeans merek Lea pada PT Matahari Departemen Store Mal SKA Pekanbaru. Hasil penelitian mendapatkan bahwa persamaan regresi yang terbentuk adalah $\mathrm{Y}=0,792+0,863 \mathrm{X} 1+0,238 \mathrm{X} 2+0,195 \mathrm{X} 3+$ $0,136 \mathrm{X} 4$, hasil penelitian menunjukkan bahwa produk (X1) mempunyai pengaruh yang paling besar dibandingkan dengan variabel bebas lainnya terhadap keputusan pembelian, dengan nilai square sebesar $93,6 \%$ dan sisanya $16,4 \%$ diikuti oleh variabel lain yang tidak diteliti dalam penelitian ini, serta hasil nilai analisis korelasi sebesar 0,732 yang berarti memiliki korelasi yang tinggi. Dari uji diperoleh hasil secara parsial bauran pemasaran berpengaruh posistif dan signifikan terhadap keputusan pembelian, sedangkan dari hasil uji $\mathrm{F}$ secara simultan bauran pemasaran berpengaruh positif dan signifikan terhadap keputusan pembelian dimana nilai Fhitung $>$ Ftabel.

\section{TINJAUAN PUSTAKA DAN HIPOTESIS \\ Pengertian Pemasaran}

AMA (American Marketing Association) yang dikutip oleh Kotler dan Keller (2016:27) menjelaskan bahwa "Marketing is the activity, set ofinstitutions, andprocesses forcreating, communicating, delivering, andex changing off erings that have value for customers, client, partners, and society large" yang artinya bahwa pemasaran merupakan suatu fungsi organisasi dan serangkaian proses untuk menciptakan, mengkomunikasikan dan memberikan nilai kepada pelanggan, klien, rekan, dan cakupan sosial yang lebih luas dan untuk mengelola 
hubungan pelanggan dengan cara yang menguntungkan organisasi dan pemangku kepentingan. Sedangkan menurut Kotler dan Keller (2016:27), sebagai berikut : "Marketing is asocietal process by which individual sand groups obtain what they need and want through creating, offering, and freely exchanging product sand services of value with others". Artinya pemasaran adalah sebuah proses kemasyarakatan dimana individu dan kelompok memperoleh apa yang mereka butuhkan dan inginkan melalui penciptaan, penawaran dan secara bebas saling bertukar produk dan jasa yang bernilai satu sama lainnya. Sedangkan menurut Downey (2003:3) dalam (Manik, 2016) pemasaran didefinisikan sebagai telaah terhadap aliran produk secara fisik dan ekonomik dari produsen melalui pedagang perantara sampai ke tangan konsumen.

\section{Bauran Pemasaran}

Kotler (2016:17) mendefinisikan bauran pemasaran sebagai berikut: "Bauran pemasaran adalah seperangkat alat pemasaran yang digunakan perusahaan untuk terus-menerus untuk mencapai tujuannya di pasar sasaran."

Dari pengertian di atas, dapat diketahui bahwa bauran pemasaran adalah rangkaian dari alat-alat yang dapat dikendalikan, dimana alat-alat itu berfungsi sebagai sebuah strategi pemasaran yang nantinya akan dibaurkan oleh perusahaan untuk membuat dan mendapatkan respon yang diinginkan dari pasar sasaran. Menurut Kotler (2016:17), ada empat komponen yang tercakup dalam aktivitas bauran pemasaran yang terkenal dengan sebutan $4 \mathrm{P}$, yakni
1. Product,
2. Price,
3. Place,
4. Promotion

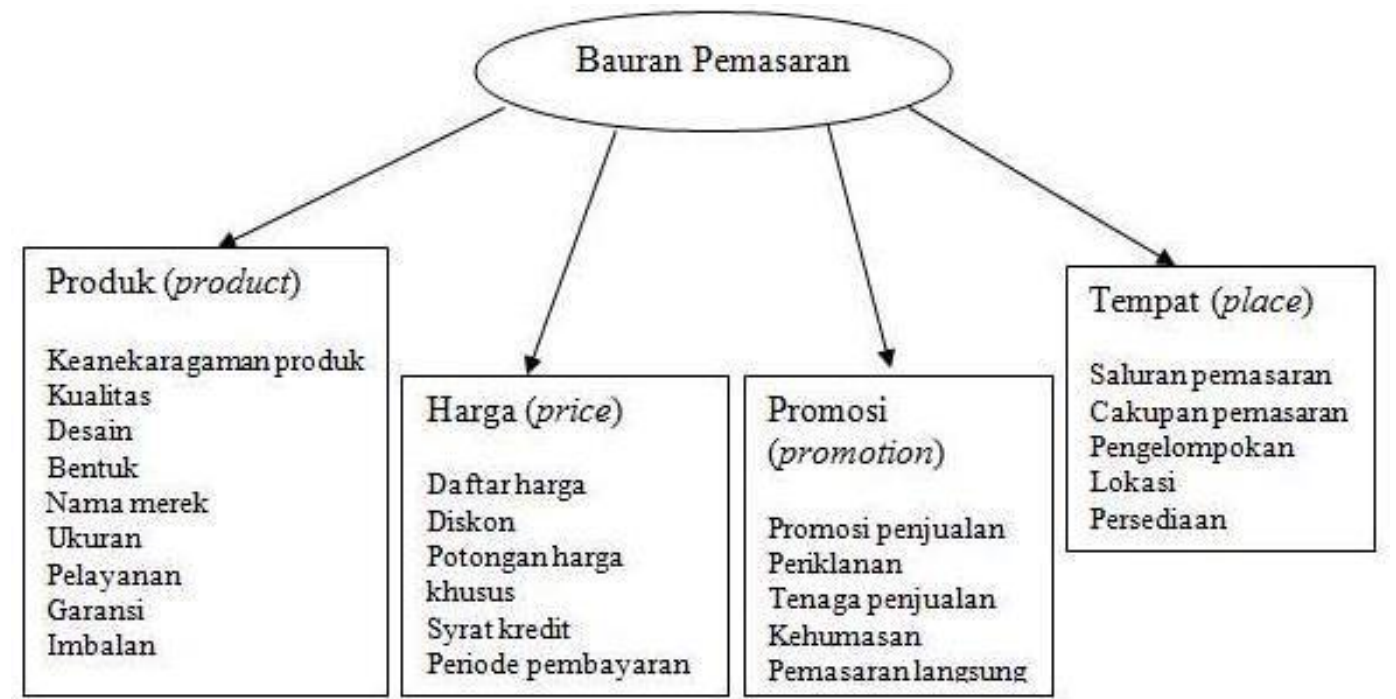

Gambar 1: Empat Dimensi dalam Bauran Pemasaran

Menurut Kotler (2016:17), ada empat komponen yang tercakup dalam aktivitas bauran pemasaran yang terkenal dengan sebutan $4 \mathrm{P}$, yakni

1. Produk.

Menurut Kotler(2007:4), produk adalah segala sesuatu yang ditawarkan kepasar untuk diperhatikan, dimiliki, digunakan, atau dikonsumsi, yang dapat memuaskan keinginan atau kebutuhan. Setiap perusahaan dalam meningkatkan volume penjualannya dan bagian pasar sasaran, perlu mengadakan usaha penyempurnaan dan 
perubahan produk kearah yang lebih baik, sehingga dapat memberikan daya tarik, keunikan, daya guna, dan tingkat kepuasan yang lebih kepada konsumen.

2. Harga

Menurut Kotler dan Amstrong (2007: 93), harga adalah jumlah dari nilai yang ditukar konsumen atas manfaat-manfaat karena memiliki atau menggunakan produk barang/jasa.

3. Promosi

Promosi atau komunikasi pemasaran menurut Kotler dan Keller (2007:204) adalah sarana yang digunakan perusahaan dalam upaya untuk menginformasikan, membujuk, dan mengingatkan konsumen langsung atau tidak langsung tentang produk dan merek yang mereka jual.

4. Place

Menurut Kotler (2007: 122), salah satu kunci menuju sukses adalah lokasi, lokasi dimulai dengan memilih komunitas. Keputusan ini sangat bergantung pada potensi pertumbuhan ekonomis dan stabilitas, persaingan, iklim politik, dan sebagainya. Sedangkan menurut Buchari (Hermanto, Apriansyah, Fikri, \& Albetris, 2019) lokasi adalah tempat perusahaan beroperasi atau tempat perusahaan melakukan kegiatan untuk menghasilkan barang dan jasa yang mementingkan segi ekonominya.

\section{Keputusan Pembelian}

Para pemasar memiliki kewajiban untuk mampu memahami konsumen, mengetahui kebutuhan konsumen, selera dari konsumen, serta bagaimana perilaku konsumen dalam mengambil keputusan pembelian. Dengan demikian, para pemasar pun mampu memproduksi barang dan jasa yang sesuai dengan kebutuhan dan keinginan konsumen. Pemahaman yang mendalam dari para pemasar mengenai konsumen, memungkinkan para konsumen akan terpengaruh dalam mengambil keputusan. Proses keputusan konsumen dalam membeli dan mengkonsumsi suatu produk barang dan jasa dipengaruhi oleh tiga faktor utama, yaitu:

1. Kegiatan yang dilakukan oleh produsen dan lembaga lainnya;

2. Faktor perbedaan individu antar konsumen;

3. Faktor lingkungan konsumen.

Proses pengambilan keputusan pembelian konsumen terdiri dari pengenalan kebutuhan, pencarian informasi, evaluasi alternatif, keputusan pembelian dan perilaku pasca pembelian. Pemahaman terhadap faktor-faktor yang mempengaruhi keputusan pembelian konsumen, akan memberikan pengetahuan kepada pemasar tentang bagaimana menyusun strategi dan komunikasi pemasaran yang lebih baik.

Keputusan pembelian konsumen dipengaruhi oleh banyak faktor. Diantaranya ialah faktor budaya, sosial, pribadi. Berikut penjelasannya menurut Kotler\&Keller (2009:166):

1. Faktor Budaya

2. Faktor Sosial

3. Faktor Pribadi

Indikator keputusan pembelian menurut Kotler dan Keller yang dialih bahasakan oleh Tjiptono (2012:184) menjelaskannya bahwa keputusan konsumen untuk melakukan pembelian suatu produk meliputi lima sub keputusan sebagai berikut:

1. Pilihan produk

2. Pilihan merek

3. Pilihan penyalur

4. Waktu pembelian.

5. Jumlah pembelian 


\section{Pengaruh Bauran Pemasaran Terhadap Keputusan Pembelian}

Bauran pemasaran merupakan bagian yang paling penting dari kegiatan pemasaran. Bauran pemasaran yang baik akan sangat membantu dalam mempertahankan konsumen, karena biaya yang diperlukan untuk mempertahankan kemauan pelanggan akan lebih sedikit jika dibandingkan biaya untuk merebut kembali pelanggan yang telah hilang atau untuk menarik konsumen yang baru yang biasanya lebih besar.

Pengaruh bauran pemasaran terhadap keputusan pembelian ini diungkapkan oleh Fandy Tjiptono (2012:30), bahwa bauran pemasaran dan keputusan pembelian berkaitan sangat erat. Bauran pemasaran memberikan suatu dorongan kepada konsumen untuk menjalin ikatan hubungan yang kuat dengan perusahaan. Dalam jangka panjang ikatan seperti ini memungkinkan perusahaan untuk memahami dengan seksama harapan konsumen seta kebutuhan mereka. Dengan demikian perusahaan dapat meningkatkan keputusan pelanggan dimana perusahaan memaksimumkan pengalaman yang menyenangkan dan meminimumkan atau meniadakan pengalaman konsumen yang kurang menyenangkan. Pada gilirannya kepuasan konsumen dapat menciptakan kesetiaan atau loyalitas pelanggan kepada perusahaan. Tingkat keterlibatan konsumen dalam pengambilan keputusan akan menyebabkan konsumen lebih banyak mencari dan menyeleksi informasi, dan lebih hati-hati dalam pengambilan keputusan

\section{Kerangka Pemikiran}

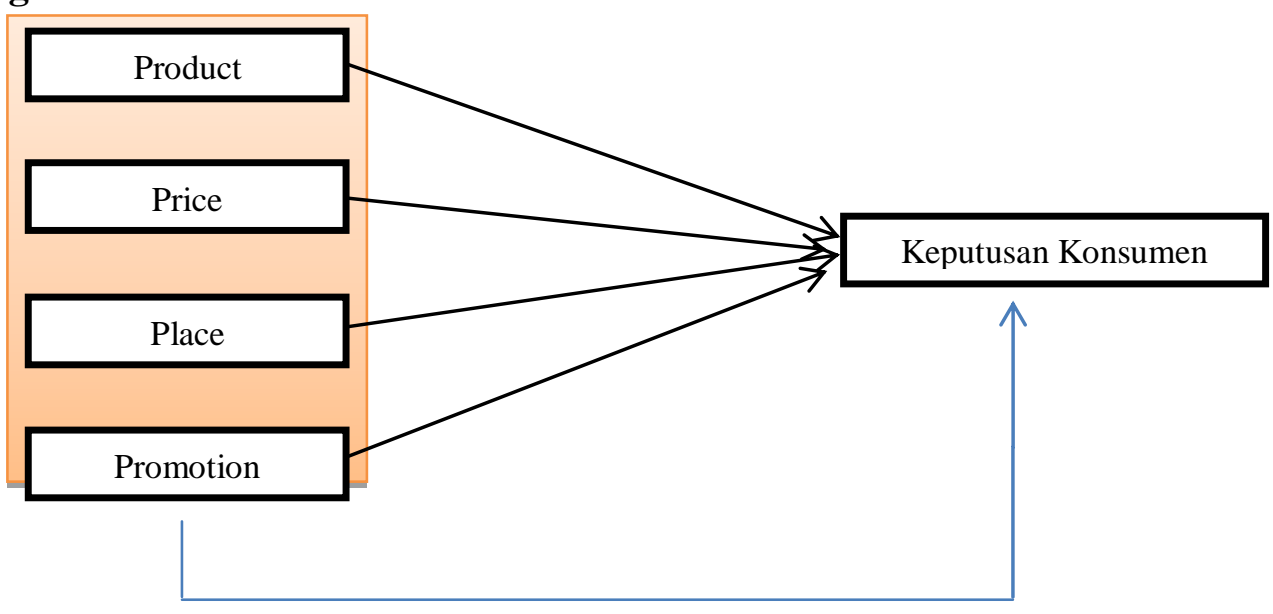

\section{Hipotesis}

Hipotesis merupakan kesimpulan awal yang didasarkan pada landasan teori yang relevan sehingga membutuhkan pengujian. Sesuai dengan perumusan masalah yang telah dijelaskan sebelumnya, maka penulis merumuskan hipotesisnya yaitu :

1. Diduga Bauran pemasaran secara simultan berpengaruh positif dan signifikan terhadap keputusan pembelian Brocco es krim di Kota Pekanbaru.

2. Diduga Bauran pemasaran secara pasrsial berpengaruh positif dan signifikan terhadap keputusan pembelian Brocco es krim di Kota Pekanbaru.

\section{METODE PENELITIAN}

Penelitian dilaksanakan di Brocco es krim Kota Pekanbaruyang berlokasi di Jl.Brigjen Katamso No. 5 Pekanbaru, sedangkan waktu penelitian dilaksanakan pada bulan Juni 2018. Guna mendukung penelitian maka jenis data yang digunakan adalah data kuantitatif dan data kualitatif. Penelitian memerlukan data baik kualitatif maupun kuantitatif untuk menguji hipotesis. Data tersebut merupakan fakta yang dikumpulkan dalam penelitian yang terdiri dari dua sumber, yaitu data primer dan data Sekunder. Populasi dalam penelitian ini adalah para konsumen yang pernah membeli Brocco es krim. Populasinya dalam penelitian ini adalah 806 
pelanggan eskrim. Dasar dari pengambilan sampel dalam penelitian ini adalah berdasarkan rumus slovin, didapatkan sampel sebanyak 89 responden. Analisis dalam penelitian ini adalah Regresi Linear Berganda menggunakan bantun program SPSS V.22 yang menguji: Uji Kualitas Data, Uji Reliabilitas, Uji Asumsi Klasik dan Uji Hipotesis serta Koefisien Determinasi.

\section{HASIL DAN PEMBAHASAN}

Uji Reliabilitas

Dari pengujian reliabilitas teknik splithalf dengan koefisien internal Spearman Brown tampak bahwa masing-masing instrumen pengukuran adalah reliabel sesuai dengan yang direkomendasikan Sugiyono (2014:178) yang menyatakan bahwa batas minimum reliabilitas yang dapat diterima adalah koefisien positif. Reliabilitas untuk kuesioner masing-masing variabel disajikan pada tabel di bawah ini:

Tabel 4: Hasil Uji Reliabilitas

\begin{tabular}{|c|c|c|c|}
\hline Variabel & Reliabilitas & Ketentuan & Kriteria \\
\hline Product (X1) & 0,804 & 0,6 & Reliabel \\
\hline Price (X2) & 0,622 & 0,6 & Reliabel \\
\hline Place (X3) & 0,756 & 0,6 & Reliabel \\
\hline Promotion (X4) & 0,849 & 0,6 & Reliabel \\
\hline Keputusan Pembelian (Y) & 0,773 & 0,6 & Reliabel \\
\hline
\end{tabular}

Sumber: Data Olahan 2019

Variabel Product (X1) adalah 0,804, Price (X2) adalah 0,662, Place adalah (X3) 0,756, Promotion (X4) adalah 0,849 dengan kriteria reliabilitas dan variabel Keputusan Pembelian (Y) adalah 0,773 dengan kriteria reliabilitas.

\section{Uji Asumsi Klasik}

\section{Uji Normalitas}

Uji normalitas bertujuan untuk menguji apakah dalam model regresi, variabel pengganggu atau residual memiliki distribusi normal. Dalam penelitian ini, Uji normalitas data dapat dilihat dari grafik $P-P$ Plot. Jika data residual normal, maka garis yang menggambarkan data sesungguhnya akan mengikuti garis diagonal (Ghozali, 2013: 161). Hasil pengujian normalitas data dengan P-P Plot untuk variabel dependen (Y) dapat dilihat pada gambar 5.1 berikut:

\section{Dependent Variable : Keputusan Pembelian}

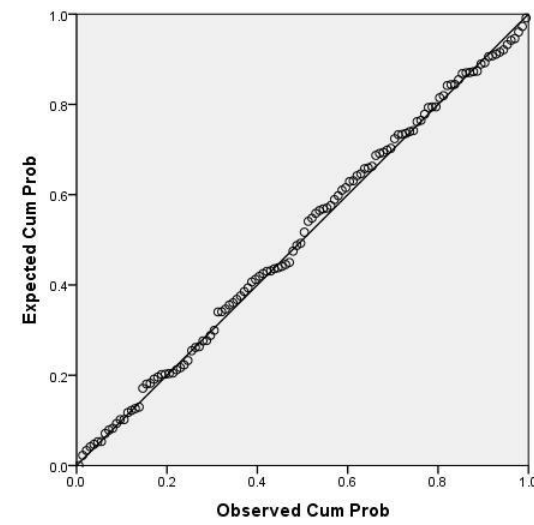

Gambar 4. Hasil Uji Normalitas Data 
Dari grafik P-P Plot dapat dilihat bahwa titik-titik menyebar di sekitar garis diagonal dan penyebarannya mengikuti arah garis diagonal. Dengan demikian, data yang digunakan dalam penelitian ini memenuhi asumsi normalitas.

\section{Hasil Uji Autokorelasi}

Uji autokolerasi bertujuan menguji apakah dalam model regresi linear ada korelasi antara kesalahan penganggu pada periode $\mathrm{t}$ dengan kesalahan pengganggu pada periode $\mathrm{t}-1$ (sebelumnya). Untuk mendeteksi ada tidaknya autokorelasi, maka diuji dengan menggunakan model Durbin-Watson. Secara umum, pengambilan keputusan dapat dilakukan dengan acuan sebagai berikut (Ghozali, 2013):

1. Jika angka D-W di bawah -2, berarti autokorelasi positif.

2. Jika angka $\mathrm{D}-\mathrm{W}$ di atas +2 , berarti autokorelasi negatif.

3. Jika angka D-W di antara -2 sampai dengan +2 , maka tidak ada autokorelasi.

Untuk menentukan ada tidaknya autokorelasi dalam penelitian ini, maka dapat dilihat pada tabel 4.47 berikut:

Tabel 5: Hasil Uji Autokorelasi

\begin{tabular}{|c|c|c|c|c|}
\hline $\mathrm{R}$ & $\mathrm{R}$ Square & $\begin{array}{c}\text { Adjusted R } \\
\text { Square }\end{array}$ & Std. ErroroftheEstimate & Durbin Watson - \\
\hline $.881^{\mathrm{a}}$ & .776 & .767 & 1.56188 & 1,673 \\
\hline
\end{tabular}

a. Predictors: (Constant), Product, Price, PlacedanPromotion

Sumber: Data Olahan 2019

Dari tabel 5 dapat diketahui bahwa nilai Durbin-Watson pada variabel independen dan variabel dependen menunjukkan nilai 1.673. Dengan demikian, nilai Durbin-Watsonberada di antara -2 dan +2 , sehingga dapat disimpulkan bahwa tidak terjadi autokorelasi pada variabel independen.

\section{Uji Multikolinearitas}

\section{Tabel 6 Hasil Uji Multikolinearitas}

\begin{tabular}{l|l|r|r}
\hline \multirow{2}{*}{\multicolumn{2}{c|}{ Model }} & \multicolumn{2}{c}{ CollinearityStatistics } \\
\cline { 3 - 4 } \multicolumn{2}{c|}{} & Tolerance & \multicolumn{1}{c}{ VIF } \\
\hline \multirow{2}{*}{1} & Constant) & & \\
\cline { 2 - 4 } & Product & .973 & 3.027 \\
\cline { 2 - 4 } & Price & .984 & 1.016 \\
\cline { 2 - 4 } & Place & .961 & 4.041 \\
\hline & Promotion & .866 & 2.041 \\
\hline
\end{tabular}

a. DependentVariable: keputusan pembelian

Sumber: Data Olahan 2019

Berdasarkan Tabel 6 diatas dapat dilihat bahwa nilai $\mathrm{VIF}<10$, berarti tidak terdapat multikolinearitas.

\section{Uji Heterokedastisitas}

Heteroskedastisitas ditandai dengan adanya pola tertentu pada grafik scatterplot. Jika titik-titik yang ada membentuk suatu pola tertentu yang teratur(bergelombang), maka terjadi heteroskedastisitas. Jika tidak ada pola yang jelas, titik-titik menyebar di atas dan dibawah 
angka nol pada sumbu Y, maka tidak heteroskedastisitas. Dalam penelitian ini tidak terdapat heterokesdasitas.

Scatterplot

Dependent Variable: Keputusan Pembelian

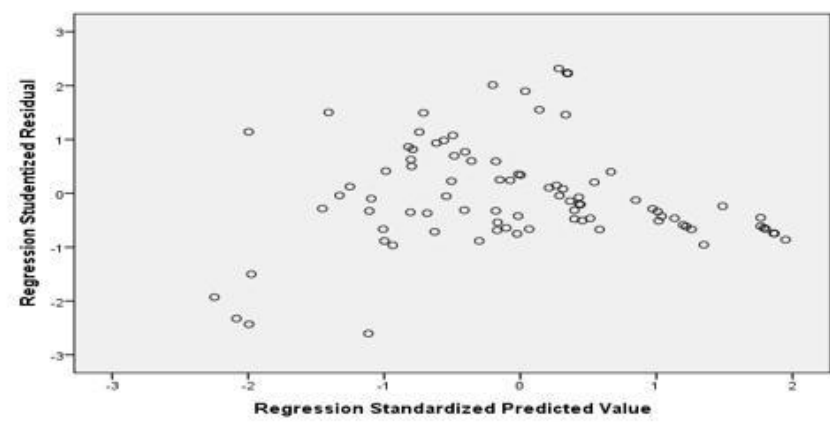

Gambar 5 Uji Heterokedastisitas

\section{Uji Regresi Linear Berganda}

Tabel 7 Hasil Uji Regresi Linear Berganda

\begin{tabular}{|c|c|c|c|c|c|c|}
\hline \multirow{2}{*}{\multicolumn{2}{|c|}{ Model }} & \multicolumn{2}{|c|}{ UnstandardizedCoefficients } & \multirow{2}{*}{$\begin{array}{c}\text { StandardizedCo efficients } \\
\text { Beta }\end{array}$} & \multirow[b]{2}{*}{$\mathrm{T}$} & \multirow[b]{2}{*}{ Sig. } \\
\hline & & $\mathrm{B}$ & Std. Error & & & \\
\hline 1 & (Constant) & 2.847 & 2.333 & & 1.220 & .228 \\
\hline & Product & .464 & .089 & .40 & 5.215 & .000 \\
\hline & Price & -.127 & .076 & .41 & 4.906 & .004 \\
\hline & Place & .413 & .133 & .31 & 6.157 & .002 \\
\hline & Promotion & .593 & .078 & .59 & 7.591 & .000 \\
\hline
\end{tabular}

a. DependentVariable: keputusan pembelian Sumber: Data Olahan 2019

Berdasarkan Tabel 7 diperoleh persamaan regresi linear berganda sebagai berikut: $\mathrm{Y}=$ $0,464 X 1-0,127 X 2+0,413 X 3+0,593 X 4$. Persamaan regresi digunakan sebagai alat ukur memprediksi dan mengevaluasi kecenderungan keputusan memilih berdasarkan asumsi apabila salah satu variabel bebasnya dikendalikan:

a. Nilai a $=2,847$ merupakan nilai konstanta apabila seluruh variabel bebas dianggap nol, maka nilai keputusan pembelian Brocco es krim konsumen adalah 2,847satuan.

b. Koefisien regresi variabel product $=0,464$, menunjukkan apabila variabel product dinaikkan 1 satuan, dan variabel X2, X3 dan X4 bernilai nol maka akan terjadi peningkatan pada keputusan pembelian sebesar 0,464 satuan. Koefisien bersifat positif artinya terdapat hubungan positif antara variabel product dengan keputusan pembelian Brocco es krim.

c. Koefisien regresi variabel Price $=-0,127$, menunjukkan apabila variabel Price dinaikkan 1 satuan, dan variabel $\mathrm{X} 1, \mathrm{X} 3$ dan $\mathrm{X} 4$ bernilai nol maka akan terjadi penurunan pada keputusan pembelian sebesar 0,127 satuan. Koefisien bersifat negatif artinya terdapat hubungan negatif antara variabel Price dengan keputusan pembelian Brocco es krim.

d. Koefisien regresi variabel Place $=0,413$, menunjukkan apabila variabel Place dinaikkan 1 satuan, dan variabel X1, X2 dan X4 bernilai nol maka akan terjadi peningkatan pada keputusan pembelian sebesar 0,413 satuan. Koefisien bersifat positif artinya terdapat hubungan positif antara variabel Place dengan keputusan pembelian Brocco es krim. 
e. Koefisien regresi variabel Promotion $=0,593$, menunjukkan apabila variabel Promotion dinaikkan 1 satuan, dan variabel X1, X2 dan X3 bernilai nol maka akan terjadi peningkatan pada keputusan pembelian sebesar 0,593 satuan. Koefisien bersifat positif artinya terdapat hubungan positif antara variabel Promotion dengan keputusan pembelian Brocco es krim.

Analisis Koefisien Determinasi $\left(\mathbf{R}^{2}\right)$

Tabel 8 Hasil Analisis Koefisien Determinasi

\begin{tabular}{|c|c|c|c|c|}
\hline $\mathrm{R}$ & $\mathrm{R}$ Square & $\begin{array}{c}\text { Adjusted } \mathrm{R} \\
\text { Square }\end{array}$ & $\begin{array}{c}\text { Std. } \\
\text { ErroroftheEstimate }\end{array}$ & Durbin Watson \\
\hline $.881^{\mathrm{a}}$ & .776 & .767 & 1.56188 & 1,673 \\
\hline
\end{tabular}

a. Predictors: (Constant), Product, Price, Place dan Promotion

Sumber: Data Olahan 2019

Berdasarkan perhitungan nilai $\mathrm{R}=0,881$, Hal ini berarti Product, Price, Place dan Promotion memiliki hubungan yang sangat erat terhadap keputusan pembelian. Sedangkan nilai adjusted $\mathrm{R}$ square sebesar 0,767. Hal ini menunjukkan bahwa variabel Product, Price, Place dan Promotion berpengaruh sebesar 77,6\% pada keputusan pembelian Brocco es krim. . Sisanya $22,4 \%$ dipengaruhi oleh faktor lain yang tidak dibahas dalam penelitian ini seperti merek produk dan tingkat pendapatan.

\section{Uji Signifikansi Secara Parsial (Uji t)}

Selanjutnya uji signifikan secara parsial untuk mengetahui apakah variabel-variabel bebas secara parsial berpengaruh terhadap variabel terikat. Pengujian dilakukan dengan dua arah dengan tingkat keyakinan 95\%. Apabila t hitung>t tabel atau nilai Sig. $<0,05$ maka hipotesis diterima atau terdapat pengaruh positif dan signifikan antara variabel bebas terhadap variabel terikat. Uji $t$ dilakukan dengan membandingkan $t$ hitung dengan $t$ tabel dimana perhitungan $\mathrm{t}$ tabel didapat dengan tingkat signifikansi 5\% diperoleh dengan cara: t tabel $=(\alpha / 2) ;(n-2)$

$$
\begin{aligned}
& =\quad(0,05 / 2) ;(89-4) \\
& =\quad(0,025 ; 85) \\
& =2,007
\end{aligned}
$$

Tabel 8: Hasil Uji Parsial (t)

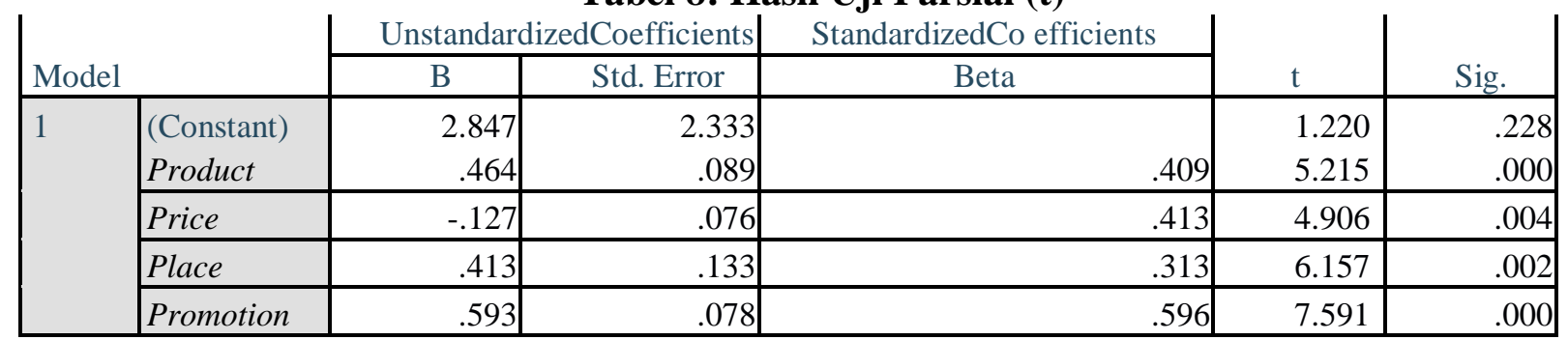

a. Dependent Variable: keputusan pembelian

Sumber: Data Olahan SPSS 22, 2019

Dari Tabel 8 diperoleh hasil pengujian parsial variabel bebas sebagai berikut ini:

1. Variabel Product dengan nilai t hitung $>$ t tabel atau 5,215>2,007 dengan tingkat signifikan $<0,05$ atau 0,000 $<0,05$. Dengan demikian variabel Product berpengaruh signifikan terhadap keputusan pembelian Brocco es krim. Artinya bahwa Product berpengaruh positif dan signifikan terhadap keputusan pembelian. Semakin tinggi Product maka keputusan pembelian semakin meningkat, begitu sebaliknya. 
2. Variabel Price dengan nilai $t$ hitung $>\mathrm{t}$ tabel atau 4,906 $>2,007$ dengan tingkat signifikan $<0,05$ atau $0,004<0,05$. Dengan demikian variabel Price berpengaruh signifikan terhadap keputusan pembelian. Artinya bahwa Price berpengaruh negative dan signifikan terhadap keputusan pembelian. Semakin tinggi Price maka keputusan pembelian semakin menurun, begitu sebaliknya.

3. Variabel Place dengan nilai t hitung $>t$ tabel atau $6,157>2,007$ dengan tingkat signifikan $<0,05$ atau $0,002<0,05$. Dengan demikian variabel Place berpengaruh signifikan terhadap keputusan pembelian. Artinya bahwa Place berpengaruh positif dan signifikan terhadap keputusan pembelian. Semakin tinggi Place maka keputusan pembelian semakin meningkat, begitu sebaliknya.

4. Variabel Promotion dengan nilai t hitung $>t$ tabel atau 7,591> 2,007 dengan tingkat signifikan $<0,05$ atau $0,000<0,05$. Dengan demikian variabel Promotion berpengaruh signifikan terhadap keputusan pembelian. Artinya bahwa Promotion berpengaruh positif dan signifikan terhadap keputusan pembelian. Semakin tinggi Promotion maka keputusan pembelian semakin meningkat, begitu sebaliknya.

\section{Uji Signifikansi Secara Simultan (Uji F)}

Analisis uji $\mathrm{F}$ dilakukan dengan membandingkan $\mathrm{F}$ hitung dengan $\mathrm{F}$ tabel. Apabila $\mathrm{F}$ hitung $>\mathrm{F}$ tabel maka hipotesis diterima atau terdapat pengaruh variabel bebas secara simultan terhadap vaiabel bebas. F hitung didapat dengan cara:

\section{Tabel 9: Hasil Uji Simultan (Uji F)}

\begin{tabular}{|c|c|c|c|c|c|c|c|}
\hline \multicolumn{8}{|c|}{ ANOVA $^{a}$} \\
\hline \multicolumn{2}{|c|}{ Model } & $\begin{array}{r}\text { Sum } \\
\text { ofSquares }\end{array}$ & df & & MeanSquare & $\mathrm{F}$ & Sig. \\
\hline \multirow[t]{3}{*}{1} & Regression & 421.724 & & 2 & 210.862 & 86.438 & $i_{b}^{000}$ \\
\hline & Residual & 121.974 & & 50 & 2.439 & & \\
\hline & Total & 543.698 & & 52 & & & \\
\hline & & & & & & & \\
\hline
\end{tabular}

Dari Tabel 9 diperoleh $\mathrm{F}$ hitung $>\mathrm{F}$ tabel atau 86,438 > 2,47 dengan tingkat signifikansi < 0,05 atau $0,000<0,05$. Berdasarkan hasil analisis dapat disimpulkan variabel Product, Price, Place dan Promotion secara simultan berpengaruh signifikan terhadap Keputusan Pembelian. Artinya bahwa Product, Price, Place dan Promotion berpengaruh positif dan signifikan terhadap Keputusan Pembelian. Semakin tinggi Product, Price, Place dan Promotion maka Keputusan Pembelian semakin meningkat, begitu sebaliknya.

\section{Kesimpulan}

Berdasarkan hasil penelitian dan pembahasan serta analisis yang telah dilakukan pada bab sebelumnya, maka pada bab ini dikemukakan kesimpulan penelitian sebagai berikut:

1. Product berpengaruh signifikan dan positif terhadap keputusan pembelian Brocco Es Krim, dengan nilai thitung $>\mathrm{t}$ tabel atau 5,215 $>$ 2,007 dengan tingkat signifikan $<0,05$ atau $0,000<0,05$.

2. Price berpengaruh signifikan dan positif terhadap keputusan pembelian Brocco Es Krim, dengan nilai thitung $>\mathrm{t}$ tabel atau 4,906 $>$ 2,007 dengan tingkat signifikan $<0,05$ atau $0,004<0,05$

3. Place berpengaruh secara signifikan dan positif terhadap keputusan pembelian Brocco Es Krim, dengan nilai t hitung $>\mathrm{t}$ tabel atau 6,157 > 2,007 dengan tingkat signifikan < 0,05 atau $0,002<0,05$. 
4. Promotion berpengaruh secara signifikan dan positif terhadap keputusan pembelian Brocco Es Krim, dengan nilai t hitung $>$ t tabel atau 7,591 > 2,007 dengan tingkat signifikan $<0,05$ atau $0,000<0,05$.

5. Terdapat pengaruh Product, Price, Place dan Promotion secara simultan terhadap Keputusan Pembelian dengan $\mathrm{F}$ hitung $>\mathrm{F}$ tabel atau 86,438 $>2,47$ dengan tingkat signifikansi $<0,05$ atau $0,000<0,05$

\section{Saran}

Berdasarkan hasil penelitian dan kesimpulan di atas, saran-saran yang diajukan dalam penelitian ini sebagai berikut :

1. Brocco Es Krim sebaiknya menciptakan variasi produk yang disukai konsumen, memperluas jaringan pemasaran dengan penetrasi pasar, misalnya membuat ritel gerai dan usaha waralaba, serta jaringan pemasaran diperluas dengan menjalin pola kemitraan dengan UKM yang bergerak di bidang makanan dan minuman.

2. Brocco Es Krim sebaiknya meningkatkan pengenalan produk untuk menjaga eksistensi di pasar, selain itu diperlukan mengadakan event-event yang dapat meningkatkan sosialisasi kepada masyarakat serta mengelola konsumen loyal dengan menjalin hubungan baik bagi pelanggan.

3. Brocco Es Krim sebaiknya memanfaatkan teknologi untuk meningkatkan mutu produk dan konsisten dengan mempertahankan produktifitas agar diterima pasar selain itu meningkatkan produksi es krim dan meningkatkan pelayanan sesuai standar layanan agar pelanggan puas.

\section{DAFTAR PUSTAKA}

Arikunto, Suharsimi, 2010. Prosedur Penelitian Suatu Pendekatan Praktik, Rineka Cipta, Jogyakarta.

Agustina, Ridha. 2017. Pengaruh Bauran Pemasaran Terhadap Keputusan Pembelian Konsumen Produk Ice Cream Walls Pada Arena Hiburan Tiara Dewata Denpasar. Universitas Mahasaraswati.

Affifudin. 2013. Dasar-dasar Manajemen. CV. Alfabeta. Bandung.

Creswell, John. 2015. Riset Pendidikan. Yogyakarta: Pustaka Pelajar.

Fahmi, Irham. 2011. Analisis Laporan Keuangan. CV. Alfabeta. Bandung.

Fandy Tjiptono. 2015. Strategi Pemasaran. Edisi Ke-4. CV Andi. Yogyakarta. Yogyakarta.

Hasibuan, Malayu. 2013. Manajemen Sumber Daya Manusia. Bumi Aksara. Jakarta.

Hermanto, Apriansyah, R., Fikri, K., \& Albetris. (2019). Pengaruh Lokasi dan Kualitas Pelayanan Terhadap Loyalitas Konsumen pada Fotocopy Anugrah Rengat. Ekonomis: Journal of Economics and Business, 3(2), 171-176. https://doi.org/10.33087/ekonomis.v3i2.78

Imam Ghozali. 2013. Aplikasi Analisis Multivariate dengan Program SPSS. Edisi Ke-7. Badan Penerbit Universitas Diponegoro. Semarang.

Kotler, Philip and Gary Amstrong. 2015. Principles of Marketing. 15e Global Edition. Pearson. 
Kotler Philip and Kevin Lane Keller. 2016. Marketing Management. 15e Global Edition. Pearson.

Manik, S. (2016). PENGARUH KUALITAS PELAYANAN TERHADAP KEPUASAN PASIEN PADA RUMAH SAKIT THURSINA DI DURI. Eko dan Bisnis: Riau Economic and Business Review, 7(1), 80-93. https://doi.org/10.1017/CBO9781107415324.004

Nopitasari, Rizki. 2016. Pengaruh Bauran Pemasaran (Product, Price, Place, Promotion) Terhadap Volume Penjualan Es Krim Pak Bos Campurdarat - Tulungagung. Universitas Universitas Nusantara PGRI Kediri.

Silviana, Mellya. 2011. Pengaruh Produk, Harga, Promosi Dan Saluran Distribusi Terhadap Keputusan Pembelian Ulang Ice Creamwall's Pada Siswa SMP dan SMA Di Kota Padang. Universitas Negeri Padang.

Sugiyono, 2014. Metode Penelitian Kuantitatif Kualitatif dan R\&D. Alfabeta. 